\title{
BRCA1/2 mutation screening in high-risk breast/ ovarian cancer families and sporadic cancer patient surveilling for hidden high-risk families
}

Dace Berzina, Miki Nakazawa-Miklasevica, Jekaterina Zestkova, Karina Aksenoka, Arvids Irmejs, Andris Gardovskis, Dagnija Kalniete, Janis Gardovskis and Edvins Miklasevics

\begin{abstract}
Background: The estimated ratio of hereditary breast/ovarian cancer (HBOC) based on family history is $1.5 \%$ in Latvia. This is significantly lower than the European average of 5-10\%. Molecular markers like mutations and SNPs can help distinguish $\mathrm{HBOC}$ patients in the sporadic breast and ovarian cancer group.

Methods: 50 patients diagnosed with HBOC in the Latvian Cancer Registry from January 2005 to December 2008 were screened for BRCA1 founder mutation-negatives and subjected to targeted resequencing of BRCA1 and BRCA2 genes. The newly found mutations were screened for in the breast and ovarian cancer group of 1075 patients by Real Time-PCR/HRM analysis and RFLP.
\end{abstract}

Results: Four BRCA2 mutations including three novel BRCA2 frameshift mutations and one previously known $B R C A 2$ frameshift mutation and one BRCA1 splicing mutation were identified. Two of the BRCA2 mutations were found in a group of consecutive breast cancer patients with a frequency of $0.51 \%$ and $0.38 \%$.

Conclusions: Molecular screening of sequential cancer patients is an important tool to identify $\mathrm{HBOC}$ families.

Keywords: BRCA2, Breast cancer, Hereditary cancer families, Mutation analysis

\section{Background}

Breast and ovarian cancers are the most common and increasing cancers among women worldwide. From the breast/ovarian cancer cases in Europe $5-10 \%$ are diagnosed as hereditary [1] which frequently have early onset [2]. The most common approach to diagnosing hereditary cancer is to investigate family history. However, hereditary breast/ovarian cancer (HBOC) is often difficult to identify by family history due to the small size of families and uncertain family history records [3]. The incidence of hereditary cancer (diagnosed according to the National Comprehensive cancer network $(\mathrm{NCCN})$ guidelines) is $1.5 \%$ of all the breast cancers in Latvia [3]. This is significantly lower than the European average. In other words, many HBOC patients may be unnoticed among the cancer patients considered sporadic, missing an opportunity to be clinically consulted for risk control.

\footnotetext{
* Correspondence: edvins.miklasevics@rsu.lv

Institute of Oncology, Riga Stradins University, Dzirciema street 16, LV1007, Riga, Latvia
}

\section{Biomed Central}

Molecular screening of all cancer patients in order to reveal pathogenic high-penetrance mutations is an obvious alternative. Mutations in the BRCA1 and BRCA2 genes are known as the main risk factors of $\mathrm{HBOC}$ and are found in about $80 \%$ of patients $[4,5]$. In Latvia, two founder mutations, c.4035delA and c.5266dupC, of the $B R C A 1$ gene dominate [6,7], but no prevalent BRCA2 mutation has been reported as yet. Molecular screening of consecutive breast and ovarian cancer patients revealed that $3.77 \%$ of breast cancer and $9.9 \%$ of ovarian cancer patients had been harboring one of the BRCA1 founder mutations [2]. Identification of new frequent mutations in either of these genes would promote the identification of more HBOC patients without substantial cost increases.

This study provides the results of our attempt to identify new $B R C A 1 / 2$ mutations in HBOC patients and estimate their usefulness for molecular screening to spot hidden hereditary breast/ovarian cancer patients without a significant family history. 


\section{Methods}

\section{Study population}

50 unrelated patients who had been diagnosed with HBOC from January 2005 to December 2008, according to the NCCN guidelines.

Blood samples for the study material had been collected from consecutive 1075 breast or ovarian cancer patients at Pauls Stradins Clinical University Hospital from January 2005 to December 2008. These patients had been screened for BRCA1 founder mutations c. $181 \mathrm{~T}>\mathrm{G}$ (BIC: $300 \mathrm{~T}>\mathrm{G})$, c.4035delA (BIC: 4154delA) and c.5266dupC (BIC: 5382insC) and found negative earlier [2]. All patients have been informed of the analyses, and they have given written consent to have their blood samples used for DNA analyses. Permission for the research project has been given by the Ethical Committee of Riga Stradins University.

Families which had at least three breast, ovarian or breast and ovarian cancer patients and one of those patients was the first degree relative to other two or the second degree relative through male were classified as $\mathrm{HBC}, \mathrm{HOC}$ or HBOC families, respectively.

\section{$B R C A 1$ and $B R C A 2$ analysis}

Genomic DNA was isolated from peripheral blood cells using the FlexiGene DNA Kit (Qiagen, Germany). Screening of the three most common BRCA1 mutations in Latvia, c. $181 \mathrm{~T}>\mathrm{G}$ (BIC: $300 \mathrm{~T}>\mathrm{G})$, c.4035delA (BIC: 4154delA) and c.5266dupC (BIC: 5382insC), was performed by multiplex PCR. The samples without $B R C A 1$ founder mutations were subjected to direct sequencing of the coding regions of BRCA1 and BRCA2 genes and analyzed by ABI PRISM 3130 (Applied Biosystems, USA).

Screening of the BRCA2 c.658delGT mutation was performed by Real Time PCR/High Resolution Melting (HRM) run on Rotor-Gene 6000 amplification (Qiagen, Germany). BRCA2 c.5244delC and c.7316delG mutations were screened by restriction fragment length polymorphism (RFLP) analysis. The PCR products were digested with AluI and BccI restriction enzymes (NEB, England), respectively. All the mutations detected in HRM and RFLP were confirmed by sequencing. All the primers were as described before [8].

\section{Results}

50 unrelated families who corresponded to the NCCN guidelines for HBOC (23 families), HBC (25) and HOC (2) were identified in Latvia from 2005 to 2008. The ethnic composition of the group matched the ethnic structure of the country: 27 Latvian (54\% of the HBOC families and $59 \%$ of the residents in Latvia), 16 Russian (32\% and 28\%), 3 Polish (6\% and 2.3\%), 2 Belarusian (4\% and 3.6\%) and 2 Ukrainian (4\% and 2.5\%) families. Screening for three BRCA1 mutations (c.181T>G, c.4035delA and c.5266dupC) revealed that 15 families were (10 HBOC, $3 \mathrm{HBC}$ and $2 \mathrm{HOC}$ ) harboring either mutation c. 4035 delA (8 families) or c.5266dupC (7 families). The distribution of the BRCA1 mutations by ethnicity was as follows: 8 Latvian (29.6\% of hereditary cancer families from the same ethnic group), 1 (6\%) Russian, 3 (100\%) Polish, 2 (100\%) Ukrainian and 1 (50\%) Belarusian. From the remaining 35 patients, 30 agreed to targeted resequencing of the $B R C A 1 / 2$ genes.

Four clinically significant mutation and thirteen polymorphisms [9-15] in the BRCA1 and BRCA2 genes were identified by targeted resequencing (Table 1 ).

777 consecutive breast cancer and 298 consecutive ovarian cancer patients were screened for the presence of any of the three $B R C A 2$ mutations found in hereditary cancer families. To detect the c.658delGT variant, Real Time PCR/HRM of exon 8 was performed. Two different melting patterns compared to the wild-type were found in 7 cases. The PCR fragments with different melting curves were sequenced and harbored either the c.658delGT or c.646delG mutation (Table 2). None of these mutations were found among the 298 ovarian cancer patients. No other carriers of mutations c.5244delC and c.7316delG were identified (Table 2).

\begin{tabular}{|c|c|c|c|c|c|}
\hline Gene & $\begin{array}{l}\text { Nucleotide } \\
\text { change }\end{array}$ & $\begin{array}{l}\text { Effect on } \\
\text { protein }\end{array}$ & NCBI SNP & $\begin{array}{l}\text { Clinical } \\
\text { significance }^{1}\end{array}$ & $\begin{array}{l}\text { Case } \\
\mathrm{n}=30\end{array}$ \\
\hline \multirow[t]{5}{*}{ BRCA1 } & c. $2311 \mathrm{~T}>\mathrm{C}$ & L771L & rs16940 & No & 3 \\
\hline & c. $3113 A>G$ & E1038G & rs16941 & No & 2 \\
\hline & C. $4308 \mathrm{~T}>\mathrm{C}$ & S1436S & rs1060915 & No & 4 \\
\hline & $\begin{array}{l}\text { c. } 4675+ \\
1 \mathrm{G}>\mathrm{A}\end{array}$ & INV15+1 & rs80358044 & Yes & 1 \\
\hline & c. $4837 A>G$ & S1613G & rs1799966 & No & 1 \\
\hline \multirow[t]{12}{*}{ BRCA2 } & c. $-41 A>G$ & $5^{\prime} U T L$ & - & Unkown & 1 \\
\hline & c. $-26 \mathrm{G}>\mathrm{A}$ & $5^{\prime} U T L$ & rs1799943 & No & 20 \\
\hline & c.658delGT & V220 (223stop) & rs80359604 & Yes & 1 \\
\hline & C. $1114 A>C$ & $\mathrm{~N} 372 \mathrm{H}$ & rs144848 & No & 1 \\
\hline & c. $3396 \mathrm{~A}>\mathrm{G}$ & K1132K & rs1801406 & No & 10 \\
\hline & c. $3807 \mathrm{~T}>\mathrm{C}$ & V1269V & rs543304 & No & 2 \\
\hline & c. $4258 \mathrm{G}>\mathrm{T}$ & D1420Y & rs28897727 & No & 2 \\
\hline & $c .4563 A>G$ & L1521L & rs206075 & No & 2 \\
\hline & c.5244delC & $\begin{array}{l}\text { S1748 } \\
\text { (1748stop) }\end{array}$ & - & Yes & 1 \\
\hline & $c .5744 C>T$ & T1915M & rs4987117 & minor & 2 \\
\hline & c. $7242 A>G$ & S2414S & rs1799955 & No & 4 \\
\hline & c.7316delG & $\begin{array}{l}\text { G2439 } \\
\text { (2468stop) }\end{array}$ & - & Yes & 1 \\
\hline
\end{tabular}

${ }^{1}$ As clinically significant were considered nonsense, frameshift and splice site mutations, as well as missense ones which are considered as such in Breast Cancer Information Core database [16]. 
Table 2 Mutations found in the BRCA2 gene in consecutive breast or ovarian cancer patients

\begin{tabular}{llll}
\hline $\begin{array}{l}\text { Nucleotide } \\
\text { change }\end{array}$ & $\begin{array}{l}\text { Effect on } \\
\text { protein }\end{array}$ & $\begin{array}{l}\text { Case } \\
\text { ( } \mathbf{n}=1075)\end{array}$ & Diagnosis/age \\
\hline c.646delG & A216 (229stop) & 3 & $\mathrm{BC} / 39,44,58$ \\
c.658delGT & V220 (223stop) & 4 & $\mathrm{BC} / 43,51,55,73$ \\
c.5244delC & S1748 (1748stop) & 0 & \\
c.7316delG & G2439 (2468stop) & 0 & \\
\hline
\end{tabular}

One HBOC patient and four patients from sporadic cancer group were identified as carriers of the c.658delGT mutation. In three non-HBOC patients the c.646delG mutation was found. Figure 1 shows family pedigrees of patients. Size of family for all patients is relatively small and some patients don't have previously known cancer cases in family. None of pedigrees of patients from consecutive patients group corresponded to criteria of $\mathrm{HBOC}$.

\section{Discussion and conclusions}

In a previous study, we had screened for $B R C A 1$ founder mutations c.4034delA and c.5266dupC in consecutive breast/ovarian cancer patients, and it showed that $57.5 \%$ of mutation carriers did not correspond to the clinical criteria of $\mathrm{HBC}$ or HBOC [2]. This indicates that a significant number of patients carrying $B R C A 1$ or $B R C A 2$ mutation are still missing an opportunity of proper counseling or surveillance of other family members. The main reason for an insufficient detection of HBOC patients based on family histories is due to the small family size resulting into a small number of relatives. In families with a larger number of relatives it is easier to diagnose hereditary cancer. The significant difference in the size of the families who were diagnosed with hereditary cancer syndromes, according to defined criteria, and in the families with non-diagnostic findings has been described previously in the population screening of the

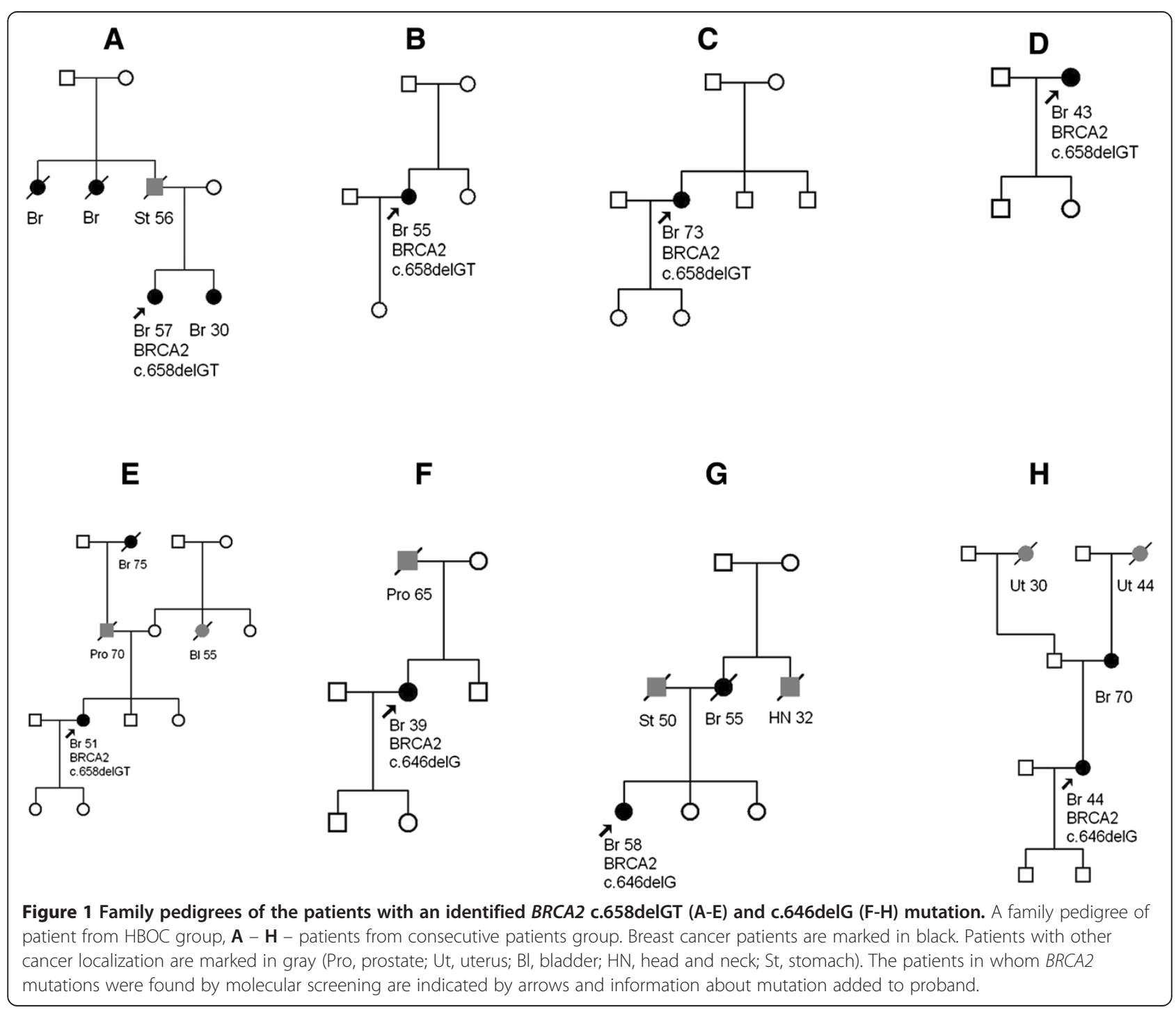


Valka region in Latvia [3]. The mean number of blood relatives within the families with hereditary cancer syndromes, according to criteria, was 13.6, whereas it was 9.5 for the families not diagnosed with hereditary cancer syndrome but whose members were carriers of the $B R C A 1$ founder mutation. In the case of hereditary breast cancer, clinical findings based on family history do not overlap with the results of molecular screening, and molecular screening reveals more mutation carriers than clinical criteria.

Our findings show that in total seven patients not diagnosed with $\mathrm{HBOC}$ based on family history were harboring deleterious mutation in BRCA2. One of the mutations which was found in the non-HBOC group of this study, c.658delGT, is listed in the BIC database (886delGT) [16]. This mutation has also been reported as a genetic risk factor of brain tumor development in the Fanconi anaemia group D1 $[13,17]$. The frequency of the mutation c.658delGT in BRCA2 is $0.9 \%$ in Polish ovarian-stomach and ovarian cancer families [18], 1.9\% in Portuguese breast cancer families [19] and $0.09 \%$ in American breast cancer patients [20]. The frequency of the c.658delGT mutation in BRCA2 in this study was $2 \%$ in the $\mathrm{HBOC}$ patient group and $0.51 \%$ in the consecutive breast cancer patient group. This is the most common BRCA2 mutation in Latvia. To our best knowledge, the $B R C A 2$ c.646delG mutation has not been reported as yet.

Despite finding 10 BRCA2 mutation carriers in the breast cancer patients, we did not find any BRCA2 mutation carriers in the ovarian cancer patients. Due to the small number of ovarian cancer patients in the HBOC patient group, we might have missed the BRCA2 mutations which tend to affect the risk of ovarian cancer. Inspecting the pedigree charts of $B R C A 2$ mutation carriers for ovarian cancer families, just one ovarian cancer family member in a BRCA2 c.7316delG carrier family was found. However, the relation between ovarian cancer and the BRCA2 mutation is uncertain because we did not analyze the mutation status of other family members except the proband.

In this study, we found $B R C A 2$ mutations with probable founder effect in patients without a significant family history using molecular screening. It can be useful to screen all consecutive breast cancer patients for the specific BRCA1 and BRCA2 mutations with founder effect.

\footnotetext{
Abbreviations

HBOC: Hereditary breast/ovarian cancer; HBC: Hereditary breast cancer; HOC: Hereditary ovarian cancer; NCCN: National comprehensive cancer network; Real Time-PCR/HRM: Real time polymerase chain reaction/high resolution melting; RFLP: Restriction fragment length polymorphism.
}

\section{Competing interests}

The authors declare that they have no conflict of interests.

\section{Authors' contributions}

DB: drafting the article, analysis and interpretation of data; MNM: drafting the article, analysis and interpretation of data; JK: analysis and interpretation of data; KA: analysis and interpretation of data; Al: revising of article for critically important intellectual content; AG: analysis and interpretation of data; DK: analysis and interpretation of data; JG: revising of article for critically important intellectual content; EM: design of experiments, final approval of the version to be published. All authors have read and approved the final manuscript.

\section{Acknowledgements}

We gratefully acknowledge the support from the ESF project No. 2009/0230/ 1DP/1.1.1.2.0/09/APIANIAA/070.

Received: 6 July 2012 Accepted: 11 June 2013

Published: 14 June 2013

\section{References}

1. Claus EB, Schildkraut JM, Thompson WD, Risch NJ: The genetic attributable risk of breast and ovarian cancer. Cancer 1996, 77:2318-2324.

2. Plakhins G, Irmejs A, Gardovskis A, et al: Genotype-phenotype correlations among BRCA1 4153delA and 5382insC mutation carriers from Latvia. BMC Med Genet 2011, 12:147.

3. Vanags A, Štrumfa I, Gardovskis A, et al: Population screening for hereditary and familial cancer syndromes in Valka district of Latvia. Hered Cancer Clin Pract 2010, 8:8.

4. Fackenthal JD, Olopade OI: Breast cancer risk associated with BRCA1 and BRCA2 in diverse populations. Nat Rev Cancer 2007, 7:937-948.

5. Ramus SJ, Gayther SA: The contribution of BRCA1 and BRCA2 to ovarian cancer. Mol Oncol 2009, 3:138-150.

6. Tikhomirova $L$, Sinicka $O$, Smite $D$, et al: High prevalence of two BRCA1 mutations, 4154delA and 5382insC, in Latvia. Fam Cancer 2005, 4(2):77-84.

7. Gardovskis A, Irmejs A, Miklaševičs E, et al: Clinical, molecular and geographical features of hereditary breast/ovarian cancer in Latvia. Hered Cancer Clin Pract 2005, 3:71-76.

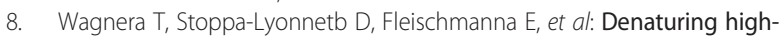
performance liquid chromatography detects reliably BRCA1 and BRCA2 mutations. Genomics 1999, 62(3):369-376.

9. De Leeneer K, Coene I, Poppe B, De Paepe A, Claes K: Genotyping of frequent BRCA1/2 SNPs with unlabeled probes: a supplement to HRMCA mutation scanning, allowing the strong reduction of sequencing burden. J Mol Diagn 2009, 11:415-419.

10. Carvalho MA, Marsillac SM, Karchin R, et al: Determination of cancer risk associated with germ line BRCA1 missense variants by functional analysis. Cancer Res 2007, 67:1494-1501.

11. Lubinski J, Phelan CM, Ghadirian P, et al: Cancer variation associated with the position of the mutation in the BRCA2 gene. Fam Cancer 2004, 3(1):1-10.

12. Offit $K$, Levran $O$, Mullaney $B$, et al: Shared genetic susceptibility to breast cancer, brain tumors, and Fanconi anemia. J Natl Cancer Inst 2003, 95(20):1548-1551.

13. Deffenbaugh AM, Frank TS, Hoffman M, Cannon-Albright L, Neuhausen SL: Characterization of common BRCA1 and BRCA2 variants. Genet Test 2002, 6:119-121.

14. Zhang B, Beeghly-Fadiel A, Long J, Zheng W: Genetic variants associated with breast-cancer risk: comprehensive research synopsis, meta-analysis, and epidemiological evidence. Lancet Oncol 2011, 12:477-488.

15. Johnson N, Fletcher O, Palles C, et al: Counting potentially functional variants in BRCA1, BRCA2 and ATM predicts breast cancer susceptibility. Hum Mol Genet 2007, 16:1051-1057.

16. National Human Genome Research Institute (NHGRI): An open access on-line breast cancer mutation data base Breast Cancer Information Core (B/C). Available at: http://research.nhgri.nih.gov/bic/. [Last accessed April 24, 2012.].

17. Alter B, Rosenberg PS, Brody LC: Clinical and molecular features associated with biallelic mutations in FANCD1/BRCA2. J Med Genet 2007, 44:1-9.

18. Jakubowska A, Scott R, Menkiszak J, et al: A high frequency of BRCA2 gene mutations in Polish families with ovarian and stomach cancer. Eur J Hum Genet 2003, 11:955-958.

19. Machado PM, Brandão RD, Cavaco BM, et al: Screening for a BRCA2 rearrangement in high-risk breast/ovarian cancer families: evidence for a 
founder effect and analysis of the associated phenotypes. $J$ Clin Oncol 2007, 25:2027-2034.

20. Malone KE, Daling JR, Doody DR, et al: Prevalence and predictors of BRCA1 and BRCA2 mutations in a population-based study of breast cancer in white and black American women ages 35 to 64 years. Cancer Res 2006, 66:8297-8308.

doi:10.1186/1471-2350-14-61

Cite this article as: Berzina et al:: BRCA1/2 mutation screening in highrisk breast/ovarian cancer families and sporadic cancer patient surveilling for hidden high-risk families. BMC Medical Genetics 2013 14:61.

\section{Submit your next manuscript to BioMed Central and take full advantage of:}

- Convenient online submission

- Thorough peer review

- No space constraints or color figure charges

- Immediate publication on acceptance

- Inclusion in PubMed, CAS, Scopus and Google Scholar

- Research which is freely available for redistribution 